\title{
Comparative Experiment of Whaling Grenades in the Japanese Whale Research Program under Special Permit (JARPA and JARPN)
}

\author{
Hajime ISHIKAWA $^{1)}$ and Hirohisa SHIGEMUNE ${ }^{2)}$ \\ 1) The Institute of Cetacean Research, 4-5 Toyomi-cho, Chuo-ku, Tokyo 104-0055, Japan \\ 2) Kyodo Senpaku Kaisha, Ltd. 4-5 Toyomi-cho, Chuo-ku, Tokyo 104-0055, Japan \\ （2007 年 8 月 30 日受領，2007 年 11 月 29 日採択）

\section{日本の鯨類捕獲調査（JARPA/JARPN）における爆発銛改良実験} \\ 石川 創 ${ }^{12}$, 重宗弘久 ${ }^{2)}$ \\ 1）財)日本鯨類研究所 $テ 104-0055$ 東京都中央区豊海町 4-5 豊海振興ビル $5 \mathrm{~F}$ \\ 2）共同船舶(株) テ 104-0055 東京都中央区豊海町 4-5 豊海振興ビル 7F
}

\begin{abstract}
The Japanese Whale Research Program under Special Permit in the Antarctic (JARPA) and in the Northwest Pacific Ocean (JARPN) has been conducted by the Institute of Cetacean Research (ICR). The lethal component of the JARPA and JARPN was an explosive harpoon used as the primary method of killing whales. In order to improve the method of whale killing, ICR and Kyodo Senpaku made improvements to the explosive harpoon. The newly developed Norwegian grenade and the improved Japanese grenade were compared to the traditional Japanese grenade. Trial firing using cubic target objects and practical experiments were conducted from 2000 to 2004 . The new Norwegian grenade and the improved Japanese grenade decreased the time to death (TTD; the time from the first harpoon strike to death of the whale) and increased the instantaneous death rate (IDR) significantly compared to the traditional Japanese grenade. Both the improved Japanese and new Norwegian grenades have common features of low rate of misfire and short explosive distance (the distance from a hit point of the harpoon to point of the grenade explosion), which increased a rate of the explosion of the grenade inside the whale's body. Comparing the two types of grenades, the Norwegian grenade had a higher IDR for smaller whales. It was also easy to handle and load because of its integrated structure. The improved Japanese grenade had the shortest TTD and the lowest rate of misfire. As there is not much difference in actual performance between the two, the lower price of the Japanese grenade may be an important factor in selecting future whaling devices.
\end{abstract}

Key word : explosive harpoon, grenade, instantaneous death rate, minke whale, time to death

Jpn. J.Zoo. Wildl. Med. 13(1) : 21-28, 2008

\section{INTRODUCTION}

The Japanese Whale Research Program under Special Permit in the Antarctic (JARPA) and in the Northwest Pacific Ocean (JARPN) has been conducted every year since the $1987 / 88$ season and 1994, respectively. In compliance with Article VIII of the International Convention for the Regulation of Whaling (ICRW), JARPA and JARPN were authorized by the Government of Japan and planned and conducted by the Institute of Cetacean Research (ICR). Since these programs required a variety of biological samples from whales, they adopted lethal sampling methods [1,2].

Lethal sampling requires careful consideration to the issue of animal welfare. Animal welfare issues in whaling have been discussed in the International Whaling Commission (IWC) since the 1960's under the headings of "Humane Killing of
Whales" or "Whale Killing Method" [3]. IWC defined "Humane Killing" as "to render an animal insensitive to pain as swiftly as is technically possible" [4]. In this sense, reducing time to death (TTD ; the time from the first harpoon strike to death of the whale) and increasing instantaneous death rate (IDR) are the primary aims in the humane killing of whales.

In the JARPA and JARPN, an explosive harpoon is used as the primary killing method. When the whale is not killed instantaneously, a second harpoon and/or large caliber rifle are used as the secondary killing method [5]. The explosive harpoon consists of a grenade mounted on an iron harpoon with barbs. The grenade for minke whales (common minke whale Balaenoptera acutorostrata and Antarctic minke whale Balaenoptera bonaerensis) was developed by Japan in the early 1980's [6]. IWC recognized that penthrite grenades have an excellent potential for causing rapid and humane death in 
struck whales [4].

In 1992, the IWC Workshop on Whale Killing Methods developed an Action Plan [7], which was revised in 1995 and 1999. ICR commenced investigations related to the whale killing methods on a regular basis from the 1993/94 season in the Antarctic (JARPA) and from 1994 in the Northwest Pacific Ocean (JARPN) in response to the Action Plan. Continuous efforts to develop gunner's shooting skills by necropsy and analysis of data successfully shortened the TTD and increased IDR $[5,8]$. Consequently, Japan has concluded that modifications to whaling equipment might further shorten TTD.

In 1996, Norway, the only country conducting commercial whaling under the ICRW, started to develop a new whaling grenade and successfully completed it in 1999. The new Norwegian grenade, Whale grenade-99 achieved $78.3 \%$ IDR and an average of 2 minutes TTD in the 2000 Norwegian whaling season $[9,10]$, making it an effective primary killing method. With the kind cooperation of Dr. Egil Ole Øen of the Norwegian School of Veterinary Science, one of the developers of the grenade, and the Government of Norway, Japan started a comparative experiment using the Norwegian and Japanese grenades in the 2001/02 JARPA.

At the same time Japan also began improvement of the Japanese penthrite grenade especially in regard to reducing misfiring of the fuse. Experiments using the Japanese grenade with the improved fuse started from the 2002/03 JARPA in conjuction with the experiments using the Norwegian grenade.

This paper presents the results of experiments that compare three whaling grenades for explosive harpoons; the new Norwegian grenade, the Japanese grenade with traditional fuse (Japanese traditional grenade) and the Japanese grenade with improved fuse (Japanese improved grenade).

\section{MATERIAL AND METHODS}

\section{Structure of grenades}

Japanese traditional grenade: This grenade consists of a fuse, penthrite cartridge ( $30 \mathrm{~g}$ for $75 \mathrm{~mm}$ caliber harpoon) and an iron cover head $[5,6]$ (Fig. 1). When the harpoon strikes and penetrates the body, the pencil rope holding the barbs is pushed back. This pulls the twine connecting the friction wire of the fuse and the pencil rope which then pulls the friction wire, causing ignition of the fuse and detonation of the penthrite cartridge [6]. In the case of the Japanese traditional grenade, it explodes later and at a longer distance from the hit point. The traditional fuse for the Japanese penthrite grenade contained "delay powder" to delay explosion of the grenade for about 1/40 of a second after the harpoon hit the target. However, it was thought that the difficulty in controlling the delay time precisely by the delay powder and the fact that the delay powder is relatively ineffective in moist conditions were the major reasons for the misfiring of the Japanese grenades.

Japanese improved grenade: The basic structure of the grenade and ignition system is the same as the traditional grenade except for the fuse. With the object of reducing

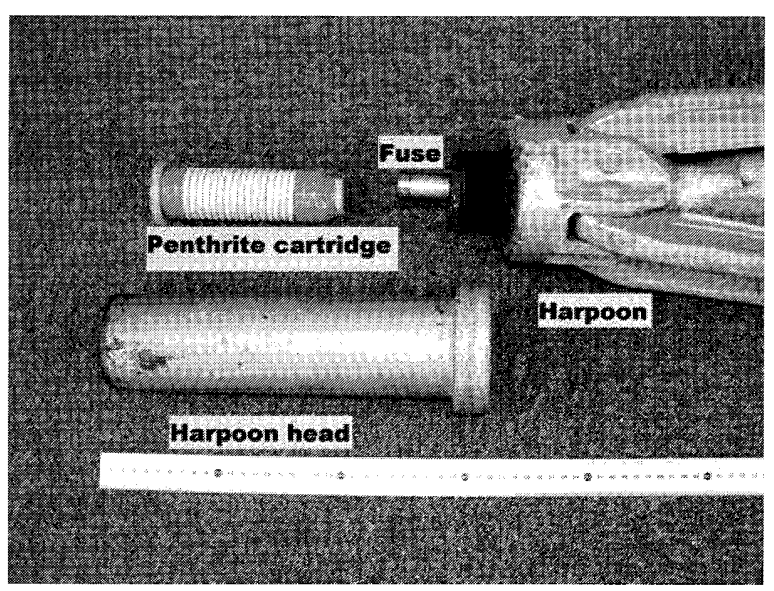

Fig. 1 Structure of the Japanese grenade. A penthrite cartridge and a fuse are loaded into a steel harpoon head just before the chase.

explosion time and improving water resistance of the fuse, the delay powder of the fuse was removed and increased priming powder was used instead.

Norwegian grenade: The Norwegian grenade employs an integrated construction. It contains $30 \mathrm{~g}$ of compressed penthrite powder, a fuse and safety device (Fig.2). Instead of the delay powder as in the Japanese grenade, it uses a mechanical trigger, which consists of two trigger hooks held in the rear case of the grenade and a trigger cord coiled in the rear case. When the harpoon hits the whale, the trigger hooks stay on the surface of the whale body and the trigger cord is extended with the harpoon penetration. The grenade explodes after the trigger cord $(65 \mathrm{~cm})$ is straightened taut and activates the fuse. This has the advantage of being retrievable if the gunners should miss the target and the grenade fails to explode.

\section{Development of connector}

For the comparative experiment, it was necessary to develop a special device, a connector, to mount the Norwegian grenade that was designed for the $50 / 60 \mathrm{~mm}$ Norwegian whaling harpoon onto the Japanese $75 \mathrm{~mm}$ harpoon (Fig. 3). In consultation with Dr. Øen, Miroku Precision Machinery Manufacturing Co. Ltd (Yokohama, Japan) developed two prototype connectors, $100 \mathrm{~mm}$ and $200 \mathrm{~mm}$ in length. On 7 May, 2000, a trial firing using dummy grenades was conducted to compare the two prototype connectors with regard to their effect on the ballistic course of the $75 \mathrm{~mm}$ harpoon. Results showed that the short type connector had a better ballistic course.

\section{Trial firing of grenades}

As there is no gun range for whaling cannons on land, trial firings of the grenades were conducted offshore using one of 


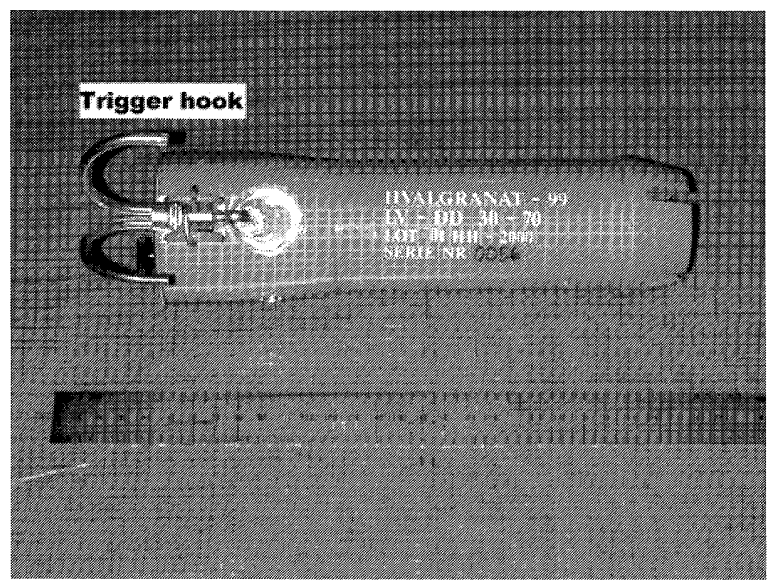

Fig. 2 Structure of the Norwegian grenade. Penthrite powder and a fuse are included in the body of the grenade.

the research vessels (catcher boats). The purpose of the trial firing was to compare explosion distance (from the hit point to the explosion point) and the explosion effect among the three types of grenades. Two trials were conducted; one off Shimonoseki (Yamaguchi pref.) on 30 October, 2000, with the new Norwegian and the Japanese improved grenade, and another off Sukumo (Kochi pref.) 26 October, 2003, with the Japanese traditional and improved grenades.

Cubic target objects (with one side $1 \mathrm{~m}$ in length for the 2000 experiment and $1.5 \mathrm{~m}$ for the 2003 experiment) made of polyethylene foam were prepared. Gunners fired at these cubic targets floating on water at a distance of ca. $50 \mathrm{~m}$ (Fig. 4). The target was replaced after several shots to avoid destruction by the harpoons. The penetration course of harpoons and the explosion points in each target were examined at port.

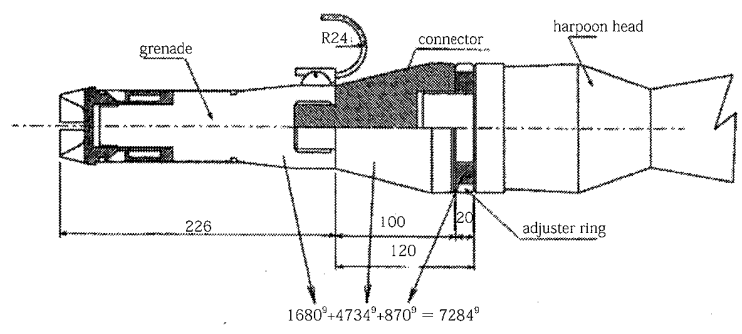

Fig. 3 Loading of the Norwegian grenade onto the Japanese harpoon. A short connecter (shaded, middle of the figure) mounts the Norwegian grenade (left of the figure) onto the Japanese $75 \mathrm{~mm}$ harpoon head (right of the figure). Adjuster ring assures placement of the trigger of the Norwegian grenade in upper position for safety reason.

\section{Comparative experiments in practical research operations}

Comparative experiments for the three types of grenades were conducted on five cruises of JARPA and JARPN from 2000 to 2003. ICR imported 100 Norwegian grenades in 2000 and used them for experiments during the 2000/01 JARPA. An additional 300 grenades were imported in 2001. Two hundreds of these were used in the 2001/02 JARPA and the 2002 JARPNII. The grenades used in the 2001/02 JARPA were slightly modified from the original model with a longer trigger cord. This modification was intended to delay the explosion as it turned out that Japanese gunners tended to shoot whales at a lower angle than the Norwegian gunners [5]. However, it appeared that the longer trigger cord broke more easily than the original one because of the power of the $75 \mathrm{~mm}$ cannon compared to the Norwegian 50/60 mm cannon. In 2002, three hundred grenades were imported for the 2002/03 JARPA and the 2003 JARPNII. Japanese improved grenades were also introduced in the 2002/03 JARPA.

During whaling operations, all whale carcasses were examined by a veterinarian or trained biological researchers. In addition to the usual necropsies to improve the whale killing method [8], they paid special attention to confirmation of explosions inside the whale body, finding the cause of misfires and measuring the explosion distances.

\section{Data set}

Table 1 shows the number of kills from which data were used for statistical analysis from each research cruise. We limited the data for the Japanese traditional grenades used for statistical analysis to match the time and area used for other grenades because different times and areas may have resulted from different body size of whales or different sea conditions which may have influenced TTD of whales. Although only Japanese improved grenades were used in the 2003/04 JARPA,

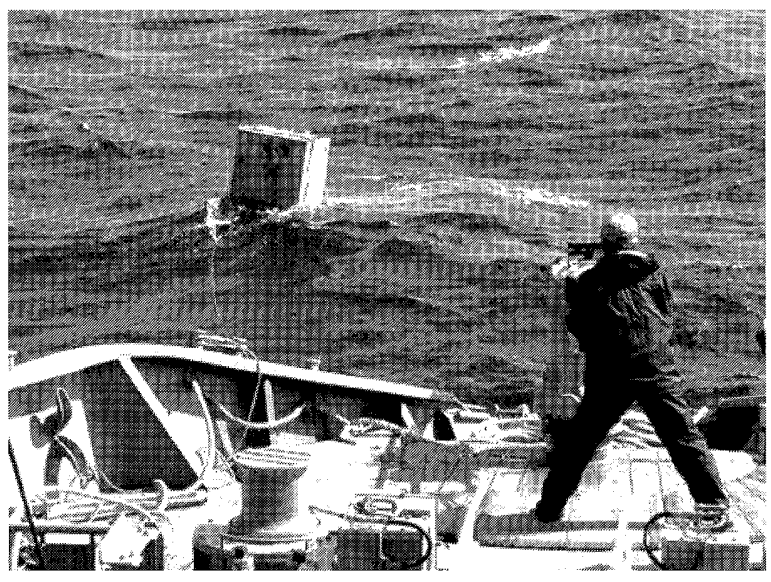

Fig. 4 A gunner on a catcher boat readies a whaling cannon to shoot a cubic target. 
these data were included for statistical analysis to increase the data set.

\section{RESULTS}

\section{Explosion distance and effect}

Table 2 shows the explosion distance for the three types of grenades. The explosion distance measured in the trial firings was the shortest in the Japanese improved grenades followed by the Norwegian and the Japanese traditional grenades. The explosion distance was also estimated during comparative experiments in practical research operations. As it was difficult to detect the precise explosion point inside the whale body, explosion distances were estimated following observation. The resulting distances expressed as mode value were ca. $80 \mathrm{~cm}$ for the Norwegian grenades, ca. $90 \mathrm{~cm}$ for the Japanese improved grenades and ca. $140 \mathrm{~cm}$ for the Japanese traditional grenades. The explosion distances estimated in whale bodies were longer than in the artificial targets made from polyethylene foam, especially for the two types of Japanese grenades. It is assumed that the pencil of the Japanese grenades that connects to the fuse ignition system was likely to have been pulled into the soft tissue of the whale body compared to the trigger hook of the Norwegian grenades that was likely to have cut and remained in the skin of the body.

Fig. 5 shows the destruction area caused by the Norwegian and the Japanese grenades. As the two types of Japanese grenades used the same penthrite cartridge, no difference of explosion effects was observed between them except for the explosion distance. Both Norwegian and Japanese grenades caused a concentric circular destruction area from the explosion point. The Norwegian grenade caused a destruction area with a trace of combustion wave about $40 \mathrm{~cm}$ in diameter, whereas the Japanese grenades caused a destruction area about $20 \mathrm{~cm}$ in diameter and with very little trace of burning.

\section{Comparison of time to death (TTD) and instantaneous death rate (IDR)}

Fig. 6 shows TTD and IDR for the three types of grenades in each experiment. TTD of the Norwegian grenades in every experiment was shorter than that for the Japanese traditional grenades, however, differences were not significant. IDR for the Norwegian grenades in every experiment was higher than that for the Japanese traditional grenades with the results from the 2001/02 JARPA showing a significant difference (chi-square test; $p=0.02$ ). All types of grenades were compared simultaneously in the 2002/03 JARPA and the Japanese improved grenades showed the shortest TTD whereas the Norwegian grenades showed the highest IDR.

When the data from all seasons were combined, comparison of TTD and IDR among the three types of grenades showed the superiority of both the Norwegian and Japanese improved grenades over the Japanese traditional grenade (Tables 3 and 4). Averaged TTD was the shortest in the Japanese improved grenade $(113.0 \mathrm{sec}$.) followed by the Norwegian grenade ( 152.5 sec.) and the Japanese traditional grenade ( 174.7 sec.). TTDs for the three types of grenades were significantly different from each other (Bonferroni multiple comparison). IDR for both the Japanese improved (44.5\%) and Norwegian grenades $(41.9 \%)$ were significantly higher than that for the Japanese traditional grenade $(32.7 \%)$, but there was no statistical difference between the Japanese improved and the Norwegian grenades (chi-square test).

Table 1. Number of kills from which data were used for comparison among three types of grenades during six cruises of JARPA (A) and JARPN (N). Data of individuals struck but re-chased were excluded. Data from the Japanese traditional grenade used in 2000/01 JARPA was limited to the same number of Norwegian grenades to match the time and area of their use as much as possible. Data from only 21 and 17 kills using the Japanese traditional grenades were collected in 2002 and 2003 JARPN respectively, because the Norwegian grenades were given priority of use. Japanese improved grenades were introduced in 2002/03 JARPA and fully used in 2003/04 JARPA.

\begin{tabular}{lccc}
\hline \multicolumn{1}{c}{ Cruise } & Japanese traditional & Norwegian & Japanese improved \\
\hline A00/01 & 76 & 76 & - \\
$\mathrm{A} 01 / 02$ & 263 & 166 & - \\
$\mathrm{N} 02$ & 21 & 74 & - \\
$\mathrm{A} 02 / 03$ & 116 & 171 & 146 \\
$\mathrm{~N} 03$ & 17 & 78 & - \\
$\mathrm{A} 03 / 04$ & - & - & 422 \\
\hline \multicolumn{1}{c}{ Total } & 493 & 565 & 568 \\
\hline
\end{tabular}




\section{Improvement of whaling explosive harpoon}

Table 2. Explosion distance (from hit point to explosion point) of three types of grenades. As it was difficult to detect the precise explosion point inside the whale body, explosion distances estimated in autopsy were expressed as mode value.

\begin{tabular}{lcccc}
\hline \multirow{2}{*}{ Grenade type } & \multicolumn{2}{c}{ Measured in trial firing } & \multicolumn{2}{c}{ Estimated in autopsy } \\
\cline { 2 - 5 } & Distance & $\mathrm{N}$ & Distance & $\mathrm{N}$ \\
\hline Japanese traditional & $105 \mathrm{~cm}$ & $1^{*}$ & Ca. $140 \mathrm{~cm}$ & 25 \\
Japanese improved & $50 \mathrm{~cm}$ & 5 & Ca. $90 \mathrm{~cm}$ & 98 \\
Norwegian & $72 \mathrm{~cm}$ & 5 & Ca. $80 \mathrm{~cm}$ & 99 \\
\hline
\end{tabular}

* Two of three trials for the Japanese traditional grenades were failed as the grenades exploded after penetration of the target.

\section{IDR in different body size}

Table 5 shows the comparison of IDR by body length for the three types of grenades. When samples were divided into large (body length $>7.5 \mathrm{~m}$ ) and small (body length $7.5 \mathrm{~m}$ or less), the Norwegian grenade showed significantly higher IDR in small whales than large whales $(p=0.0012)$.

Confirmation of an explosion inside the body and rate of misfire

The explosive harpoon is effective when it exploded inside the whale body. Although most of the harpoons always explode after hitting targets, it is important to know whether they exploded inside or outside the body. Table 6 shows the confirmation rate of an explosion inside the body and a misfire rate for the three types of grenades. The rate of confirmation of explosion inside the whale body was the highest for the Japanese improved grenades $(77.6 \%)$ followed by the Norwegian grenade $(69.6 \%)$ and the lowest for the Japanese traditional grenades $(35.5 \%)$. As confirmation of explosion was made by the existence of shrapnel or small parts of the grenade, the confirmation rate may not exactly equal the actual internal explosion rate. However, the confirmation rate for both the Japanese improved and Norwegian grenades was double that for the Japanese traditional grenade.

The rate of misfire was the lowest for the Japanese improved grenade $(0.7 \%)$ followed by the Norwegian grenade $(3.8 \%)$ and the highest for the Japanese traditional grenade $(13.0 \%)$. Most causes of misfires in the Norwegian grenade $(72.7 \%$ of the cases) resulted from the breaking of the trigger cord. The breaking of the trigger cord often occurred when a harpoon destroyed the skull, producing many sharp bone pieces. On the other hand, it was observed that many of the misfiring of the Japanese traditional grenade were caused by malfunction of the fuse.

\section{DISCUSSION}

Superiority of Norwegian and Japanese improved grenades

The series of experiments described above revealed the superiority of both the Norwegian and Japanese improved grenades over the Japanese traditional grenade. Compared to
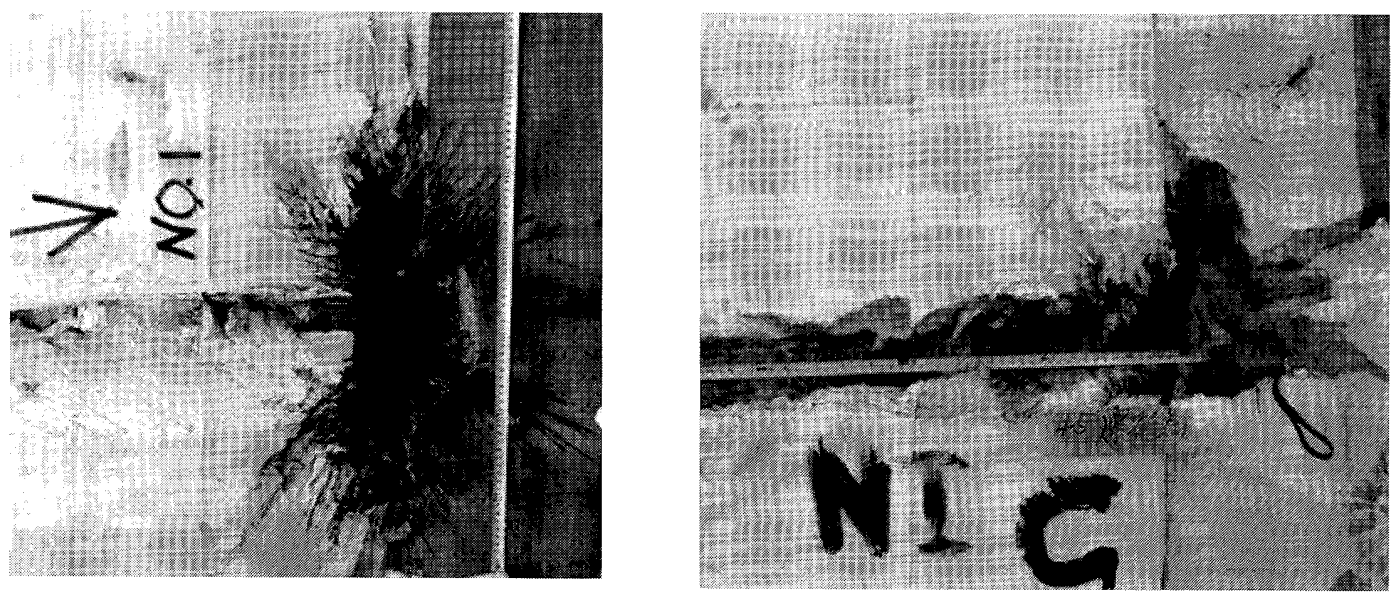

Fig. 5 Cross section of the urethane cubic targets shows traces of explosion from the different types of grenades. Left: Norwegian grenade, right: Japanese grenade. Thickness of each colored urethane is $25 \mathrm{~cm}$. 

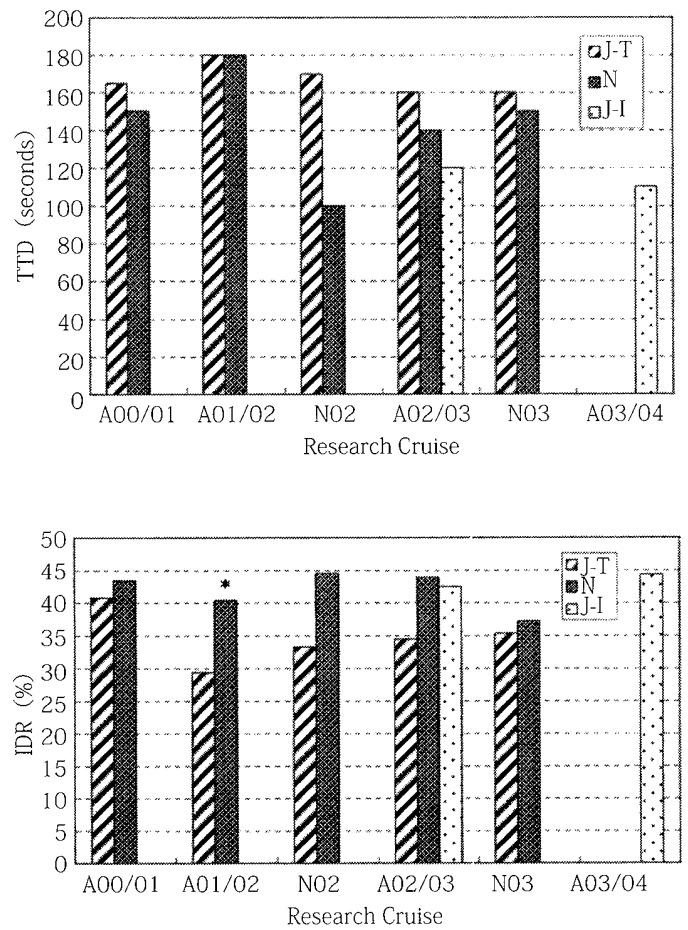

Fig. 6 Comparison of time to death (TTD, upper) and instantaneous death rate (IDR, lower) for three types of grenades, the Japanese traditional ( $\mathrm{J}-\mathrm{T}$; oblique), the Norwegian ( $\mathrm{N}$; gray) and Japanese improved (J-I; dotted). TTD is shown by median. Data of individuals struck but re-chased were excluded. The comparative data for the Japanese grenade in the 2000/01 JARPA was extracted from the same area and season that the Norwegian grenades were used. For abbreviations of each research cruise, refer to Table 1.

* $(p=0.02)$

the Japanese traditional grenade, both of the new grenades significantly increased IDR and decreased TTD. These are the primary objectives for the humane killing of wild animals.

Common features of both the Norwegian and Japanese improved grenades are a short explosion distance and a low rate of misfire. Both of the new grenades shortened the explosion distance more than $50 \mathrm{~cm}$ compared to the Japanese traditional grenade and decreased the rate of misfire from $13.0 \%$ to $3.8 \%$ (Norwegian) and 0.7\% (Japanese improved), respectively.

The Norwegian grenade has a mechanical system with trigger hooks and a cord to ensure a stable explosion distance. The built-in fuse is designed to work certainly when the trigger is pulled properly. However, the rate of misfires from the Norwegian grenades in our experiments was relative high. The most common cause of misfires in the Norwegian grenades
Table 3. Time to death (TTD; left) and the Instantaneous death rate (IDR; right) for three types of grenades, Norwegian (N), Japanese improved (J-I) and Japanese traditional $(\mathrm{J}-\mathrm{T})$ grenades.

\begin{tabular}{cccc}
\hline Grenade type & TTD (mean) & IDR (\%) & N \\
\hline N & 152.5 & 41.9 & 565 \\
J-I & 113.0 & 44.5 & 568 \\
J-T & 174.7 & 32.7 & 493 \\
\hline
\end{tabular}

was the breaking of the trigger system (hook or cord). Only two cases of misfire after activation of the fuse were recorded. Therefore the Norwegian grenade is reliable unless the trigger system malfunctions. It is considered that the Japanese $75 \mathrm{~mm}$ harpoon with higher power and heavier weight tends to break the trigger system of the Norwegian grenade especially when it hits the hard tissue of whales as the Norwegian grenade was developed for the Norwegian 50/60 mm whaling cannon and harpoon.

The Japanese improved grenade attained a short explosion distance and low rate of misfire when the "delay powder" was removed from the fuse of the traditional grenade. This increased the water resistance of the fuse and drastically decreased the rate of misfire. Furthermore, removal of the "delay powder" also shortened the explosion distance, which was from the tip of the harpoon to the pencil rope holding the barbs $(\mathrm{ca} .50 \mathrm{~cm}$ ) plus the distance that the pencil rope was pulled into the body with the harpoon penetration.

It is obvious that both the short explosion distance and the low misfire rate contributed to success in both TTD and IDR, because these advantages increased the number of explosions of the grenade inside the whale before the harpoon penetrated through the body. Ishikawa and Shigemune (2005) [5] described that the best way to harpoon the whale was with an internal track of thorax $\rightarrow$ skull, penetration of the thorax or abdomen $\rightarrow$ thorax. Among these three tracks, the penetration at the thorax presents the shortest internal distance. Although there was no precise data on the width of the thorax of minke whales, the estimated thorax width was from $80 \mathrm{~cm}$ to 200 $\mathrm{cm}$ depending on body length (Fig. 7). It is suggested that the Japanese traditional grenades may have exploded after the harpoon penetrated through the body when the harpoon directory hit the thorax of minke whales with a body length of less than $7.5 \mathrm{~m}$. The confirmation rate of explosion inside the body (Table 6) showed that the Norwegian and Japanese improved grenades exploded inside the body of most of minke whales except when the harpoon hit the wrong part of the body (e.g. caudal part of the body).

\section{Comparison between Norwegian and Japanese improved grenades \\ When the two types of new grenades were compared,}


Table 4. Comparison of the Time to death (TTD; left) and the Instantaneous death rate (IDR; right) using three types of grenades, Norwegian (N), Japanese traditional (J-T) and Japanese improved (J-I) grenades. TTD in the Japanese improved grenade was significantly shorter than others (Bonferroni multiple comparison). IDR in both the Norwegian and Japanese improved grenades were significantly higher than that for the Japanese traditional grenade, but there was no statistical difference between the two grenades.

\begin{tabular}{ccc}
\hline & TTD & \\
\hline & J-T & J-I \\
J-T & - & $<0.0001^{*}$ \\
$\mathrm{~N}$ & $0.0174^{*}$ & $<0.0001^{*}$ \\
\hline
\end{tabular}

\begin{tabular}{ccc}
\hline & IDR & \\
\hline & J-T & J-I \\
J-T & - & $<0.0001^{*}$ \\
$\mathrm{~N}$ & $0.0023^{*}$ & 0.4112 \\
\hline
\end{tabular}

Table 5. Comparison of the instantaneous death rate (IDR) by body length for three types of grenades, Japanese traditional, Japanese improved and Norwegian grenades. Norwegian grenade showed significantly higher IDR in small whales than large whales $(* p=0.0012)$.

\begin{tabular}{cccc}
\hline Body length & $\begin{array}{c}\text { Japanese } \\
\text { traditional }\end{array}$ & Norwegian* & $\begin{array}{c}\text { Japanese } \\
\text { improved }\end{array}$ \\
\hline $7.5 \mathrm{~m}>$ & $\begin{array}{c}36.4 \% \\
(\mathrm{~N}=132)\end{array}$ & $\begin{array}{c}51.9 \% \\
(\mathrm{~N}=183)\end{array}$ & $\begin{array}{c}51.1 \% \\
(\mathrm{~N}=135)\end{array}$ \\
$7.5 \mathrm{~m} \leqq$ & $\begin{array}{c}31.3 \% \\
(\mathrm{~N}=361)\end{array}$ & $\begin{array}{c}37.2 \% \\
(\mathrm{~N}=382)\end{array}$ & $\begin{array}{c}42.5 \% \\
(\mathrm{~N}=433)\end{array}$ \\
\hline
\end{tabular}

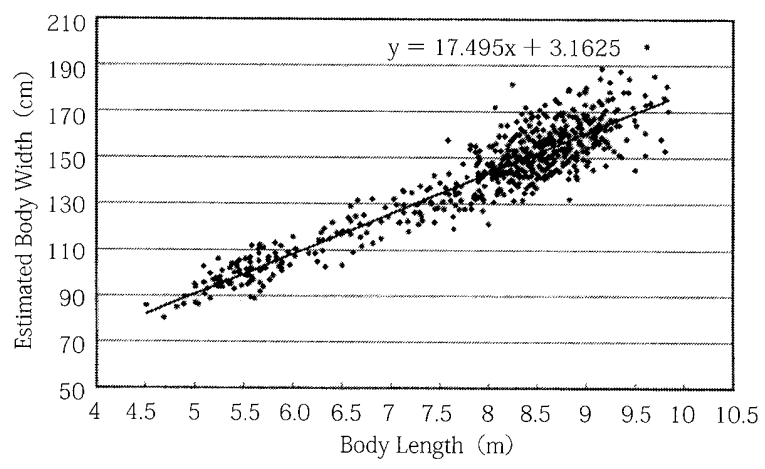

Fig. 7 Estimated thorax width of Antarctic minke whales by body length. The width was calculated by the following formula; girth at axilla / 3.14. Measurement of the girth was obtained from 1991/92 and 1993/94 JARPA.

the Norwegian grenades had a higher IDR for small minke whales. This is because of the shorter explosion distance of the Norwegian grenade, though this might be a disadvantage for larger whales. As another advantage, the experiment with the artificial targets revealed that the Norwegian grenades produced hyper-thermo explosive gas inside the target. The Japanese grenades (both the traditional and improved) have

Table 6. Confirmation rate of internal explosion and misfire rate for three types of grenades, Japanese traditional, Japanese improved and Norwegian grenades.

\begin{tabular}{cccc}
\hline & $\begin{array}{c}\text { Japanese } \\
\text { traditional }\end{array}$ & Norwegian & $\begin{array}{c}\text { Japanese } \\
\text { improved }\end{array}$ \\
\hline $\begin{array}{c}\text { Confirmation rate of } \\
\text { internal explosion }\end{array}$ & $35.5 \%$ & $69.6 \%$ & $77.6 \%$ \\
Misfire rate & $13.0 \%$ & $3.8 \%$ & $0.7 \%$ \\
$\mathrm{~N}$ & 493 & 565 & 568 \\
\hline
\end{tabular}

an iron head covering the penthrite cartridge, which produces shrapnel after exploding rather than spreads hot gas inside the whale body. Although it was not reflected in the TTD data, it is assumed that the Norwegian grenades may take full advantage of the penthrite qualities that produce hyper-thermo explosive gas with hypersonic shockwaves.

On the other hand, the Japanese improved grenades had the advantages of the shortest TTD and the lowest rate of misfire. The explosion distance of the Japanese improved grenades was slightly longer than the Norwegian grenades. As Japanese gunners tend to shoot whales at a lower angle than Norwegian gunners [5], the slightly longer explosion distance seems to produce better results for the killing of large minke whales compared to the Norwegian grenades. For this reason, the Norwegian grenades with a longer trigger cord were tested in the 2001/02 JARPA. However, the longer trigger cord was easier to break than the original one. As mentioned above, the Norwegian grenade was developed for the Norwegian whaling cannon whereas the Japanese grenade with its simple and solid structure was developed to fit the more powerful Japanese 75 mm cannon.

In conclusion, there is not much difference in the actual performance of the two newer whale killing devices. Consideration of other practical aspects may therefore be more important when selecting future whaling devices.

Comparing maneuverability, gunners on the Japanese research vessels felt that the easy handling and loading of the integral Norwegian grenade were an advantage compared to 
the separated structure of the Japanese grenade. On the other hand, the Japanese grenade has an advantage related to storage in the limited space of the research vessels. Because the bulky iron cover of the Japanese grenades can be separated and kept outside the powder store, it occupies a smaller space in the vessel than the Norwegian grenades with their special large container.

Stable supply and cost of devices are very important factors not only in commercial operations but also in scientific research. Although the Norwegian grenades can be reused when the gunner misses the target, the estimated cost of the grenade is more than double that of the Japanese grenade. This is because the cost of the Norwegian grenade includes a special container, import tax and delivery charges in addition to the price of the grenade itself* . Furthermore, the fluctuating value of the yen also affects the price. In the 2003/04 experiment, the retail price of the Norwegian grenade in Japan was nearly three times that of the Japanese grenade because the value of the yen dropped in that period. Considering these factors, it seems likely that the Japanese improved grenade would be the first selection for use in future Japanese whaling operations.

* Although the Norwegian government decided to reduce the domestic price of the grenade after recovery of development costs, the retail price in Japan was still higher than that for the Japanese grenade.

\section{ACKNOWLEDGEMENTS}

We wish to express our deep gratitude to Dr. Egil Ole $\varnothing$ en of the Norwegian School of Veterinary Science and the Government of Norway. Dr. Øen kindly invited one of the authors to Norway so that he would have an opportunity to study the newly developed Norwegian grenade on board the whaling vessel during the field tests in 1999. During the Japanese experiments, he also supervised development of the connector and lectured the Japanese crews of the research vessels about Norwegian grenades.

Data on whale killing methods was collected with the cooperation of many crew members on the research fleet. We thank all of them for their contribution. We are indebted to Drs. Seiji Otani and Toshihiro Mogoe and Messrs. Takeharu Bando and Tatsuya Isoda of ICR, who conducted necropsies of whales during many research cruises. We also thank Messrs. Masakatsu Mori, Masaomi Tsunekawa and Kazuki Fukutome of Kyodo Senpaku Kaisha, for their cooperation in the analysis of data.

\section{要 約}

財)日本鯨類研究所は, 国際捕鯨取締条約第 8 条に基づき 日本政府が発給した特別許可による鯨類捕獲調查を，南極海 (JARPA) 抽よび北西太平洋 (JARPN) で行っている. 鯨類捕 獲調查では, 致死的調査における動物福祉を向上させるため, 詳細なデータ収集と解析に基づく鯨の致死時間（TTD）短縮お よび即死率 (IDR) 向上の努力が払われている。漁具改良によ
る致死時間短縮を目指し, 2000 年から 2004 年にかけて鯨の 捕獲に用いる爆発銛に搭載する銛先（グレネード）の改良実験 を行った。ノルウェーが 1999 年に開発した新型グレネードお よび，日本の旧型グレネードの信管を改良した改良型グレネー ドを，旧型グレネードとともに比較実験した。ノルウェーグレ ネードおよび改良型グレネードは旧型と比較して TTD および IDR を有意に改善した。人工標的射撃実験及び洋上での検死結 果から，その理由は両者ともに銛命中から爆発までの距離が短 縮されたこと，抢よび不発率が減少したことにより，グレネー ドの鯨体内での爆発率が大幅に向上したためと考えられた。ノ ルウェーグレネードと国産改良型グレネードを比較した場合, 前者は小型個体の即死率が高い一方, 後者は致死時間が短く不 発率が低いなど, 両者は捕殺手段として優劣つけがたかったが, コストと安定供給の側面からは将来の捕鯨漁具として国産改良 型グレネードが推奨された。

キーワード : グレネード, 即死率, 致死時間, 爆発銛, ミン ククジラ

\section{REFERENCES}

1. Nagasaki F. 1990. The case for scientific whaling. Nature 344: 189-190.

2. Ohsumi S. 1995. The necessity of employing lethal methods in the study of whale resources. In Research on Whales, pp.13-23. The Institute of Cetacean Research, Tokyo.

3. Gambell R. 1980. The International Whaling Commission and the humane killing of whales. The document HK1 presented to the Workshop on Humane Killing Techniques for Whales, November 1980 (unpublished).

4. IWC. 1980. Report of the workshop on humane killing techniques for whales. Document IWC/33/15 presented to the 33rd IWC Technical Committee, July 1981 (unpublished). 18pp.

5. Ishikawa H. and Shigemune H. 2005. Improvements in more humane killing methods of Antarctic minke whales, Balaenoptera bonaerensis, in the Japanese Whale Research Program under Special Permit in the Antarctic Sea (JARPA). Jpn J Zoo Wildl Med $10: 27-34$.

6. Government of Japan. 1992. Development of penthrite explosive harpoons. Document IWC/44/HKW13 presented to the Workshop on Whale Killing Methods, June 1992 (unpublished).

7. IWC. 1993. Chairman's report of the forty-fourth annual meeting. Rep Int Whal Commn, 43: 11-53.

8. Ishikawa H. 1999. Research activity on whale killing methods in the Japanese Whale research Program in the Antarctic Sea and Northwestern Pacific Ocean (JARPA and JARPN). Document IWC/51/WK16 presented to the Workshop on Whale Killing Methods, May. 1999 (unpublished) 8pp.

9. Øen EO. 2003. Improvements in hunting and killing methods for minke whales in Norway 1981-2003. Document IWC/55/WK17 presented to the Workshop on Whale Killing Methods and Associated Welfare Issues, June 2003 (unpublished).

10. IWC. 2004. Report of the Workshop on Whale Killing Methods and Associated Welfare Issues. Annual Report of the International Whaling Commission 2003, p85-101. 